\title{
O ESTATUTO RENOVADO DA PASSAGEM AO ATO*
}

Maria Celina Pinheiro Guimarães

Psicanalista. Mestre em psicologia clínica pela PUCRio. Psicóloga da Polícia Militar do Estado do Rio de Janeiro (primeirotenente PM PSI).
RESUMO: Pretende-se investigar o conceito lacaniano de ato. Para isso, adotamos, em primeiro lugar, o fio condutor do seminário $\mathrm{O}$ ato psicanalítico (1967-68) para analisar o conceito de ato em cinco teses fundamentais. Em seguida, procura-se aproximar os conceitos de ato analítico e de passagem ao ato com base na hipótese de um caráter constitutivamente falho do ato. Por fim, busca-se explicitar a noção de passagem ao ato "falha", interpretando-a como a falha do ato que aponta para a irrupção da verdade do objeto a.

Palavras-chave: Ato, ato analítico, passagem ao ato, objeto a.

ABSTRACT: The renewed status of the passage to the act. The purpose of this paper is to investigate Lacan's concept of act. Therefore, firstly, under the guiding-thread of Lacan's seminary The Psychoanalytical Act (1967-68), the concept of act in five main theses is analyzed. Next, a connection is made on the concept of psychoanalytical act with that of passage to the act on the basis of the hypothesis of a constitutive failure of the act. Lastly, the notion of a "failed passage to the act" as that failure which reveals the truth of object a is interpreted.

Keywords: Act, psychoanalytical act, passage to the act, object a.

\footnotetext{
"O ato é falho porque o sujeito se intromete."

(Graciela Brodsky)
}

\section{DAS FACES DE ATO E DE SUA NÃO-PLENITUDE}

Pretendemos desenvolver algumas teses de Lacan relativas ao estatuto do ato. A referência principal para a demonstração dessas teses será o décimo quinto seminário de Lacan: O ato psicanalítico (1967-68). Isso porque o ato analítico é tido por

\footnotetext{
* Este artigo tem como base um capítulo de nossa dissertação de mestrado, intitulada "A passagem ao ato falha. Da angústia ao ato na teoria lacaniana”, orientada por Marcus André Vieira, a quem agradeço pelo comprometimento em relação às ideias aqui expostas.
} 
Lacan como o conceito mais apropriado para lançar luz sobre o tema do ato. ${ }^{1}$ Será a partir desse conceito e da teoria que daí se desenvolve que as diversas modalidades de ato - ato falho, passagem ao ato, acting out — serão reconsideradas por Lacan.

As subdivisões da primeira seção introduzem aquilo que identificamos como as cinco teses fundamentais a respeito do ato. Seguindo o fio do Seminário 15, desenvolveremos essas teses partindo dos conceitos de objeto a e angústia, tais como são compreendidos por Lacan em seu décimo seminário: A angústia (196263). Entre a angústia e o ato há, como mostraremos, um objeto a ser considerado e uma relação de causa a ser investigada. A segunda seção deste artigo comporta um duplo objetivo: completar a análise das teses desenvolvidas com elementos que precisaram estrategicamente ficar de fora e preparar o terreno para a introdução da casuística. Será aí que passaremos a concentrar nossa atenção mais especificamente no tema que constitui o interesse maior desse artigo, a saber, o da passagem ao ato. Por fim, a terceira e última seção apresenta um fragmento de caso que, a nosso ver, permite conectar a teoria com a clínica do ato.

\section{AS TESES FUNDAMENTAIS A RESPEITO DO ATO \\ 1. Todo ato implica um correlato significante}

Lacan inicia o seminário sobre $O$ ato psicanalítico com uma revisão de algumas concepções teóricas a respeito do que se chama, pelo termo geral, a ação. Se ele parte daí é com o propósito de realizar uma “operação de varredura” (LACAN, 1967-68, 15/11/67) nesse vasto e confuso terreno a fim de, então, poder situar o ato, estabelecendo seu limite em relação à ação.

Depois de considerar e criticar as teorias empiristas e biologistas que explicam a ação a partir dos paradigmas do arco reflexo e da descarga da tensão, Lacan se pergunta por que a teoria psicanalítica manifestou e ainda manifesta uma inclinação tão grande a tomá-los como apoio, concluindo que não está em posição de situar o ato em relação a nenhum dos dois modelos. Pelo contrário, diz ele, "impõe-se precisamente distinguir de saída o ato da motricidade" (LACAN, 1967-68, 22/11/67). Para Lacan, portanto, o ato está longe de corresponder a uma resposta do organismo — seja da ordem do reflexo ou da descarga da tensão - aos estímulos que se lhe endereçam. Entretanto, se ele pode aproveitar alguma coisa desses modelos, isso é condicionado a seu próprio ato de transpor o conceito de resposta à dimensão significante.

\footnotetext{
${ }^{1}$ Essa ideia é manifesta por Lacan no Seminário 15, assim como no resumo do seminário 0 ato psicanalítico. Nesse, encontramos a seguinte afirmação: “o ato psicanalítico parece apropriado a reverberar com mais luz sobre o ato, por ser ato a ser reproduzido pelo próprio fazer que ele ordena" (LACAN, 1967-68/2003, p.371). Naquele, ver lição de 20/3/68.
} 
Esse é, então, o primeiro ponto a ser esclarecido e trabalhado por Lacan quanto ao tema em questão: o ato não equivale à ação realizada, caracterizando-se, antes, por suas coordenadas simbólicas. "Pois na dimensão do ato vem à baila [...] a inscrição em algum lugar, o correlato de significante que, na verdade, não falta jamais no que constitui um ato” (LACAN, 1967-68, 15/11/67). Logo, na medida que há ato, que se mistura à tarefa (ação) que o sustenta, trata-se, para Lacan, de uma intervenção propriamente significante.

As formulações reunidas em torno dessa primeira tese ratificam de forma contundente o que, em seminários anteriores, Lacan já havia dito — de maneira mais dispersa talvez - a respeito do ato. Isso se torna evidente, por exemplo, quando ele afirma nesse seminário que “o ato é, por sua própria dimensão, um dizer” (LACAN, 1967-68, 17/1/68). Essa concepção está presente desde o começo do seu ensino. Em Os escritos técnicos de Freud (1953-54), Lacan estabelece uma equivalência entre ato e fala a partir de uma consideração a respeito do acting out e afirma que é preciso "encontrar num ato o seu sentido de palavra" (LACAN, 1986, p. 279). Aliás, essa constitui a descoberta freudiana, por excelência, em relação ao ato falho e ao ato sintomático.

Ninguém menos que Freud, desde sua investigação em A psicopatologia da vida cotidiana, atenta para o que costumava passar despercebido, a saber, que tudo que diz respeito à ação equivocada, à ação acidental ou sintomática diz respeito à dimensão do que Lacan virá a nomear como simbólico, constitutiva de todo ato. Se o ato

toma seu valor, sua articulação de ato significativo com relação ao que Freud então introduz como inconsciente, certamente não é porque ele se apresente, se coloque como ato. É totalmente o contrário. [...] Este ato vai colocar seu sentido precisamente no que se trata de atacar, de abalar, seu sentido ao abrigo da inabilidade, da falha (LACAN, 1967-68, 22/11/67).

Contudo, mesmo depois de Freud trazer a ideia de que a falha é apenas um abrigo atrás do qual se dissimulam os atos propriamente ditos, continua-se, segundo Lacan, “a pensá-los em função da falha, sem dar um sentido mais pleno ao termo ato” (LACAN, 1967-68, 29/11/67). Essa será, então, uma de suas ambições desse seminário: esclarecer o que é o ato, fazendo recair sobre ele a ênfase de sua abordagem. Já se entrevê, então, o novo enfoque que Lacan dará a esse tema logo no começo do seminário, quando ele deixa claro que o essencial do lapso, do ato falho, do ato sintomático, está na sua "face de ato" (LACAN, 1967-68, 22/11/67). O que isso significa?

$\mathrm{O}$ ato é um fato, um feito, que se inscreve como significante. Contudo, o correlato de significante que caracteriza o ato não dá conta “do todo” do ato, 
pois há nele um aspecto que não se deixa apreender pelo significante. Pode-se dizer que esse aspecto é justamente a ocorrência do ato, sua existência como tal. Uma vez que um gesto é executado ou uma fala é proferida, é estruturalmente impossível, por mais que se tente, eliminar o registro do que ali surgiu como ato, seja ele falho ou não. Pois, se de um lado, o significante inscreve, faz e refaz sentidos e significados (BARROS, 2005), de outro, ele não dispõe do fato do ato ter ocorrido, ainda que possa atenuá-lo, consertá-lo, disfarçá-lo, ressignificá-lo, etc.

O ato, portanto, não é todo permeável ao significante e o que escapa a ele é o que Lacan denomina de "face de ato". Não se trata de dividir o ato em duas faces, uma face significante e uma face de ato "propriamente dito", mas de marcar que há um aspecto do ato que "não se deixa reabsorver em seu valor significante" (ALLOUCH, 1997, p.340).

\section{O Outro está no horizonte do ato}

Lacan lançará mão de um evento histórico que, por exemplificar tão bem pelo menos três aspectos fundamentais do ato, ganha um estatuto paradigmático em seu ensino. Trata-se do célebre episódio em que César atravessa o rio Rubicão. ${ }^{2}$ O primeiro ponto que se destaca do exemplo diz respeito ao que identificamos aqui como a primeira tese: o valor de ato dessa travessia não está na ação realizada por César, no seu esforço físico, mas no seu caráter significante. Afinal, "ultrapassá-lo era entrar na terra-mãe. A terra da República, aquela que abordar era violar” (LACAN, 1967-68, 10/01/68).

Essa citação de Lacan coloca em destaque um segundo aspecto desse gesto simbólico de César: seu ato realiza a ultrapassagem de um limiar sancionado pela lei, produzindo um efeito de ruptura. Depois de atravessar o limite que o Rubicão demarcava, ou seja, de ultrapassar as coordenadas simbólicas que regiam as leis da época, César não será mais o mesmo. Seu ato inscreve, necessariamente, um antes e um depois, devido à ruptura e à transformação que ele efetua.

O exemplo do Rubicão comporta ainda outra tese de Lacan a respeito do ato. Ei-la: não há ato sem o Outro. Ainda que essa tese seja um desdobramento da primeira, uma vez que não há intervenção significante que não se dê no campo do Outro, há nela uma nuance fundamental que julgamos indispensável ressaltar: “a dimensão do Outro, na medida que o ato vem testemunhar algo, não é mais

\footnotetext{
${ }^{2}$ Em 49 a.C., o general romano Caio Júlio César atravessou o rio Rubicão com seu exército, transgredindo a lei do Senado que determinava o licenciamento das tropas toda vez que o general de Roma entrasse na Itália pelo norte. Este ato foi uma declaração de guerra contra Pompeu, que detinha poder sobre Roma. César sabia que seu ato não tinha volta: ou ele e seus soldados tomavam a cidade, ou Pompeu os destruiria. Seu ato acabava de transformar o rumo da história.
} 
eliminável” (LACAN, 1967-68, 17/1/68). Por ora, daremos menos importância à dimensão indelével do Outro do que à ideia do testemunho do ato no Outro, apesar de essa oração depender daquela para obter seu sentido pleno. Vamos mostrar aqui que o ato, para se constituir como tal, precisa ser testemunhado e recebido pelo Outro.

Se esse córrego, denominado Rubicão, não estivesse situado em determinado lugar no contexto da cultura, a ação de atravessá-lo não se constituiria como ato. A cultura define previamente o que é o Rubicão. Então, quando César o atravessa, ele realiza um ato. Mas, só há ato porque a transposição desse córrego causa efeito no contexto da cultura. Dividindo em dois tempos isso que, no caso de César, se dá em um momento só, teríamos: no primeiro tempo, a travessia do córrego como uma ação e, no segundo, a leitura que dele é feita, ou melhor, a leitura feita pelo sujeito da leitura que dessa ação o Outro dá seu testemunho, com o que, e somente, ganha a ação seu valor de ato.

$\mathrm{O}$ ato de César teve grande alcance na história. Entretanto, a incidência do ato no Outro não precisa ter, necessariamente, esse caráter evidente e público. O Outro representa a cultura, o social, de um modo particular para cada sujeito. Logo, não há nenhuma evidência a respeito do que produzirá efeito de ato no Outro, pois o Outro é, para cada um, um. O importante é que, como efeito de ato, a alteridade que o Outro representa está sujeita a se transformar, assim como o próprio sujeito.

\section{No instante do ato, não há sujeito nem Outro}

Ora, demonstrada a tese de que não há ato que não se dê no horizonte do Outro, teremos agora que defender sua antítese, de que no ato não há sujeito nem Outro? De certa forma, sim. De outra, não. Procuraremos dar conta aqui das seguintes afirmativas: "uma dimensão comum do ato é a de não comportar, no seu instante, a presença do sujeito” (LACAN, 1967-68, 29/11/67) e “o ato é sem Outro" (Lacan apud Brodsky, 2004, p.200). O conceito de objeto a será o fio condutor que nos permitirá abordar as oposições entre ato e sujeito e entre e ato e Outro. Na realidade, veremos que basta demonstrar uma delas, para que a outra seja imediatamente elucidada. Partiremos, então, da primeira oposição.

De saída, convém assinalar que essa tese refere-se à ligação estrutural do ato com a temporalidade. Um ato se realiza num instante. Esse é o seu tempo lógico de ação. A temporalidade do ato encontra-se no corte que ele instaura, na surpresa de seu acontecimento, no efeito de novidade que ele produz. Se o ato entra na repetição, seu caráter de ato desaparece, pois nada se opõe mais a ele do que a temporalidade de duração. É precisamente no instante do ato, nem antes nem depois dele, portanto, que não há sujeito nem Outro. E se defendemos que o Outro está no "horizonte” do ato, decerto não quisemos dizer que o instante 
do ato é marcado pela presença do Outro. Quanto ao sujeito, veremos adiante que é após o ato que ele reaparece, com sua presença renovada.

No instante do ato, o que se faz presente é o objeto a. Lancemos mão da concepção de Lacan de que a presença do objeto a na cena implica o ofuscamento do sujeito, do desejo, ou seja, do sujeito do desejo (LACAN, 2005). Sujeito e objeto a estabelecem, entre si, uma relação de alternância: quando um está presente, o outro se ausenta. Isso porque o objeto a só é causa de desejo através da falta que sua ausência instaura.

No seminário XV, Lacan reafirmará a função da causa de forma muito clara.

"O sujeito depende desta causa que o faz dividido que se chama objeto a, eis quem assina o que é importante de ser sublinhado: que o sujeito não é causa de si, que ele é consequência da perda e que seria preciso que ele se colocasse na consequência da perda, a que constitui o objeto a, para saber o que lhe falta." (LACAN, 1967-68, $10 / 1 / 68)$

E mais: em relação ao tema central desse seminário, Lacan conferirá ao objeto a um status especial. "O objeto perdido inicial de toda a gênese analítica, esse que Freud martela em toda sua época do nascimento do inconsciente, ele está aí, esse objeto perdido, causa do desejo. Teremos que vê-lo como no princípio do ato" (LACAN, 1967-68, 10/1/68).

Se a invisibilidade do objeto é condição para o sujeito ser causado em seu desejo (VIEIRA, 2005), sua presença, ao contrário, não apenas impossibilita o desejo, como provoca o mais pungente dos afetos: a angústia. No seu apogeu, a angústia - como sinal da supremacia do objeto a na cena — acarreta a exclusão do sujeito, ou seja, ela se dá no horizonte do sem-sujeito. O ato, por sua vez, sendo o "único correlato polar do lugar da angústia” (LACAN, 2005, p.344), também é, portanto, no fulgurar de seu instante, sem sujeito.

Não podemos deixar de nos referir aqui à conexão entre ato e angústia que Lacan estabelece no Seminário X, ao afirmar que "agir é arrancar da angústia a própria certeza. Agir é realizar uma transferência de angústia” (LACAN, 2005, p.88). Vê-se delineada, dessa forma, uma relação intrínseca entre o ato e a certeza que se engendra a partir da angústia. "Estritamente a angústia, único afeto que não engana, traz a certeza do objeto” (VIDAL, 1993, p.216). Como a essência do ato advém da angústia, é o objeto, o a, que aciona — sem a menor sombra de dúvida - o ato, transferindo para ele sua certeza. Passado seu instante, ou seja, depois que o ato, impulsionado pelo objeto a, efetua uma transformação da angústia, o sujeito pode reaparecer na cena de outro modo, renovado. Daí, a chance de podermos afirmar que o ato se constitui como um remanejamento da causa. 
Agora será mais fácil mostrar que no instante do ato também não há Outro, pois, "o Outro é um campo marcado pela mesma finitude que o próprio sujeito” (LACAN, 1967-68, 28/2/68). Não é só o sujeito que tem sua possibilidade de existência condicionada à subtração do objeto a como falta. Sujeito e Outro constituem-se no mesmo processo em que o objeto a se destaca, necessariamente, de ambos. Logo, no instante em que ele volta a se apresentar, o Outro, assim como o sujeito, tem sua possibilidade de existência aniquilada.

Vê-se, assim, que não está em questão, entre o sujeito e o Outro, a disputa pela autoria do ato. Isso porque, no instante do ato, não há sujeito nem Outro. É no só-depois, após o corte que o ato produz, que há, então, a reconfiguração do Outro e a relocalização do sujeito. Aí sim, a posteriori, o sujeito pode e deve se haver com seu ato.

\section{0 sujeito reencontra, após o ato, sua presença renovada}

Essa tese é, na realidade, proferida por Lacan em relação à passagem ao ato. O que ele afirma é o seguinte: “a passagem ao ato é aquilo além do que o sujeito reencontra sua presença como renovada, mas nada mais” (LACAN, 1967-68, 29/11/67). Temos aqui o propósito de demonstrar como essa afirmativa pode ser estendida ao ato, uma vez que a passagem ao ato e o ato - no que pese a radical diferença que os separe - têm a mesma estrutura.

Lacan, para dar ao ato o seu sentido pleno, este do qual ele parte, "este que vale desde sempre, relativo ao estatuto do ato” (LACAN, 1967-68, 22/11/67), nomeia dois adjetivos que o qualificam: novo e inaudito. $\mathrm{O}$ ato constitui-se como um verdadeiro começo, justamente no que esse começo tem de novidade, de marca inaugural. Ele "é ligado à determinação do começo, e muito especialmente, ali onde há a necessidade de fazer um, precisamente porque não existe" (LACAN, 1967-68, 10/1/68). É aí que reside a verdadeira estrutura do ato.

Através de um trecho do poema de Rimbaud intitulado "Por uma razão", Lacan pretende ilustrar como no terreno do ato há a ultrapassagem de certo limite que poderia se chamar, segundo ele, "suscitar um novo desejo" (LACAN, 1967-68, 10/1/68). Ainda que não insista quanto a isso, não podemos deixar passar despercebida a ligação que ele estabelece, a partir desse poema, entre ato e desejo.

Teria o ato, então, a função de remanejar a causa do desejo, através do corte que ele produz? Se isso procede, há um percurso lógico desencadeado pelo objeto a que, esquematicamente, poderia ser dividido em quatro tempos: $1^{\circ}$ ) a angústia surge, desprovida de causa, mas não de objeto; $2^{\circ}$ ) a certeza engendrada pelo objeto da angústia - o objeto a — impulsiona o ato; $3^{\circ}$ ) o ato aplaca a angústia e, simultaneamente, reativa o desejo; $4^{\circ}$ ) a função da causa volta a se exercer, suscitando um novo desejo. 
Logo, a tese aqui em questão nos faz crer que o ato produz o efeito de resgatar a presença do sujeito do desejo — anulada no instante do ato — mas, depois dele, necessariamente renovada. O que caracteriza e define um ato, como já vimos, é a transformação e a renovação que ele produz no sujeito a partir do corte que ele instaura. Essas características são essenciais, portanto, para que um ato - seja ele passagem ao ato ou não - seja qualificado como tal.

Nem todo ato é passagem ao ato, mas toda passagem ao ato tem a estrutura do ato. Tanto o ato analítico quanto a passagem ao ato pertencem ao cenário em que se dá a suspensão de toda a ordem prévia pela irrupção do objeto a e a reconstituição conjunta de sujeito e Outro sob o signo do inaudito, do renovado e do recomeço.

\section{Todo ato, exceto o suicidio, é falho}

Nosso objetivo aqui é - por meio da tese de Lacan de que todo ato é, em última instância, falho - desconfiar do caráter negativo e destrutivo com o qual a passagem ao ato é — inclusive no campo psicanalítico — identificada. No seminário $\mathrm{O}$ ato psicanalítico, assim como no conjunto de seu ensino, Lacan não favorece esse tipo de leitura.

Com o que foi desenvolvido nas teses anteriores, chegamos à concepção de que o ato se caracteriza, em essência, pela ruptura que ele efetua. Contudo, se essa concepção do ato como corte é tomada de forma isolada, fora do contexto que a sustenta, corre-se o risco de interpretá-la no sentido de que o ato é algo que, necessariamente, tem que aniquilar, ferir, destruir, matar. É assim que a passagem ao ato, sobretudo, costuma ser concebida.

Se até então o caminho que percorremos serviu para demonstrar que o corte que o ato produz compõe uma das faces que o identifica, agora, acompanharemos Lacan na tese - à primeira vista oposta a essa concepção - de que todo ato fracassa como corte, exceto o suicídio. Primeiro, precisamos fornecer alguma clareza à ideia de que todo ato é falho, para, em seguida considerarmos o suicídio como exceção à regra.

Não há qualquer garantia, do lado do significante, de que um ato, ainda que considerado bem sucedido, não comporte uma intenção diferente ou mesmo oposta à que o moveu. Por mais que o ato não provoque a priori dúvida sobre seu triunfo, necessariamente ele falha, segundo Lacan, na medida que jamais tem assegurada a verdade de sua motivação. Nesse sentido, “todo o ato, mesmo quando não porta esse pequeno indício de malogro, não deixará de cair exatamente sob o mesmo domínio; ou seja, pode ser levantada a questão de uma outra verdade que não a desta intenção" (LACAN, 1967-68, 6/12/67).

O significante não pode assegurar a verdade última — supondo que ela existisse - do ato. Ainda que um significante produza certo efeito de corte - 
como bem nos mostram certos chistes, atos falhos, etc. - - ele se agrega a outros significantes formando novos e numerosos sentidos que fazem fracassar a ideia de um corte derradeiro.

Pode-se afirmar que o ato é sempre fracassado pelo simples fato de ele não poder realizar uma ruptura absoluta. No momento em que ele enceta a ruptura, de imediato, ele é reinserido no Outro. Podemos dizer que ao corte produzido pelo ato segue uma costura no Outro. Todo ato encontra, inevitavelmente, uma inscrição no Outro, o que faz com que a própria ideia de corte absoluto fracasse. Por isso Lacan diz que "o suicídio é o único ato capaz de ter êxito sem qualquer falha” (LACAN, 1974/2003, p.541). Ele é o único ato que de fato foi ao fim do corte que ele implica, que decreta uma ruptura definitiva. Depois dele, o sujeito não reencontra sua presença como renovada, pois não há mais sujeito, não há mais Outro; é o fim de tudo.

Segundo Allouch, o fato de Lacan ter respondido de modo negativo à possibilidade de haver um ato que realiza em si mesmo sua plenitude de ato dá ao conceito de ato psicanalítico toda sua pertinência (ALLOUCH, 1997). O ato analítico também é fracassado, pois quando ele opera a ruptura, essa ruptura é recebida no Outro, recolhida e integrada no corpo social. Parece mais pertinente, segundo Allouch, falar das diferentes espécies de fracasso do que do sucesso absoluto do ato que, como vimos, só o suicídio pode realizar.

Assim, na medida que os conceitos de ato analítico e de passagem ao ato são equiparados - pelo corte que ambos efetuam, pelo fracasso desse corte como corte absoluto e por sua dimensão significante - a diferença entre essas duas modalidades de ato deve ser buscada em outro lugar. De todo modo, dado que todo ato é em última instância falho e dado que a reputada negatividade da passagem ao ato - exceto no êxito do suicídio - está de algum modo ligada ao seu triunfo como ato, podemos nos sentir autorizados a repensar, à luz do princípio do manejo clínico, o estatuto e o valor da passagem ao ato "falha". Considerando que a passagem ao ato, assim como o ato, é, mesmo e talvez justamente na medida de seu fracasso, sempre princípio de uma mutação no sujeito, fica provisoriamente suspensa a ideia essencialmente negativa e razoavelmente difundida no campo psicanalítico de que ela comporta o princípio do aniquilamento do sujeito.

\section{DA IMPOSSIBILIDADE DO SABER À PASSAGEM AO ATO FALHA}

A partir de alguns indícios da reabsorção do conceito de passagem ao ato no conceito de ato psicanalítico e da definição de Lacan do ato analítico como uma passagem ao ato esclarecida ou advertida, ${ }^{3}$ Allouch interroga-se a respeito do que

\footnotetext{
${ }^{3}$ Lacan utiliza as expressões "passagem ao ato esclarecida" e "sujeito advertido" ao se referir à transformação, efetuada pelo ato analítico, do psicanalisando em psicanalista (LACAN, 1967-68, 13/3/68). Allouch defende no lugar da expressão "passagem ao ato esclarecida", a
} 
operaria a diferença entre esses conceitos, se é que ela ainda existiria (ALLOUCH, 1997). Segundo ele, em nenhum outro momento do ensino de Lacan como esse do Seminário XV, a passagem ao ato foi tão claramente situada como ato. Dada essa caracterização do ato analítico, uma questão se coloca de imediato: não há mais distinção entre ato e passagem ao ato? Ou, a passagem ao ato, dividindo-se em duas, passaria a ter dois estatutos, a advertida e a não-advertida, sendo a primeira equivalente ao ato analítico?

Evitando "uma armadilha binarista do tudo-ou-nada na relação do sujeito com o saber", Allouch defende a ideia de que a passagem ao ato não pode ser definida pela simples negação da passagem ao ato advertida. Para ele, não faz sentido falar de passagem ao ato não advertida — o que equivaleria a passagem ao ato cega, ignorante — - mas sim, de passagem ao ato com valor de advertência, sendo ela mesma a advertência em questão.

O sujeito que comete uma tal passagem ao ato também não é sem saber da sua importância, sua importância de advertência, e desse modo, com efeito, se vê sublinhada a face de ato da passagem ao ato, que é o que salta aos olhos, em primeiro lugar, à leitura sobre O ato psicanalítico.” (ALLOUCH, 1997, p.345)

A distinção entre passagem ao ato advertência e passagem ao ato advertida se localizaria, então, segundo ele, na relação do sujeito com o Outro. Enquanto nesta o Outro se apresentaria barrado, "reduzido ao essencial resíduo do saber e rejeitado como tal” (idem), naquela, mostrar-se-ia sem furo, sem brecha para o sujeito que "trata de uma certa maneira, na sua própria passagem ao ato, uma falha inaceitável de saber no lugar do Outro” (idem). Em ambos os casos, vemos que está em causa a relação entre saber e ato.

A diferença entre ato analítico e passagem ao ato é marcada de forma mais explícita por outros autores que não deixam de partir, também, de uma oposição entre o ato e o saber. ${ }^{4}$ No instante de sua realização, o ato aniquila o saber. "Que haja uma maior ou menor elaboração que fundamente e prepare o ato e que em alguns casos o suceda, isto em nada modifica a disposição estrutural que torna disjuntos saber e ato” (SOUZA, 1991, p.6).

expressão "passagem ao ato advertida", empregada por Lacan no contexto do passe, pois, "falar de ato esclarecido é tão perigoso quanto nomear um grande Outro" (ALLOUCH, 2005, p.344). Além de que, assim formulada, ela lhe permite responder à questão da identificação dos conceitos de passagem ao ato e de ato.

${ }^{4}$ A esse respeito, conferir o livro de Graciela Brodsky Short story: os princípios do ato analítico (2004) e os artigos de Neuza Santos Souza: A propósito do acting out (1991) e A angústia na experiência analítica (2005). 
Evidenciando a inconsistência do Outro, a sua falha, o ato analítico levaria o sujeito a

"revisitar e reformular sua relação com o saber ao preço, não da vida nem do sujeito, mas do saber suposto sujeito, ao sacrifício da miragem do sujeito suposto saber falsificado, essa ilusão tão cara — querida, custosa — ilusão que, acenando com o saber do Outro como fiador último, nos impede de inventar respostas, de verdadeiramente criar." (SOUZA, 1991, p.8-9)

Assim, enquanto no ato analítico o sujeito faz a experiência do saber como impossível, a passagem ao ato pode ser apreendida como uma recusa ao saber, como um não-querer-saber absoluto, que equivale, em última instância, a um não-querer-saber nada da impossibilidade do saber. Trata-se aí de uma tentativa de saída dos equívocos do pensamento e do jogo do significante (MILLER, 2006). Frente à impossibilidade que marca o saber, a passagem ao ato apresenta-se como uma forma radical de "não querer saber mais nada" (MILLER, 2005, p.75). Mas essa recusa, ela acaba se consumando de dois modos possíveis. O primeiro, aquele em que a passagem ao ato alcança seu pleno êxito, isto é, somente no suicídio, ela "aniquila o discurso; inexorável, desata o laço social, diz não a todo saber" (SOUZA, 1991, p.8)..$^{5}$ Mas no segundo, aquele em que ela falha — isto é, todas as vezes em que ela não consuma o ato suicida - , a recusa ao saber se manifesta na forma paradoxal de uma reiteração da falha estrutural do saber, falha essa de que o sujeito, na presente passagem ao ato, justamente "não quer saber".

O que se observa aqui é que o modo específico de a passagem ao ato recusar o saber, qual seja, o não-querer-saber nada daquela impossibilidade do saber - de que o sujeito do ato analítico justamente faz experiência em seu modo particular de recusa - acaba por implicar, pela via de uma tácita negação dupla, uma tácita afirmação do saber. Isso tem consequências importantes.

Uma vez que o sujeito venha a sobreviver à radicalidade daquele ato em que expressa sua recusa, ele se acha de imediato às voltas não com sua recusa, mas com sua afirmação do saber. E no entanto, tão claro é que esse ato, em última instância afirmador do saber, falhou — afinal, eis aí o sujeito que não se suicidou - , que ela, passagem ao ato, como falha da afirmação do saber, pode se oferecer como uma via de acesso à experiência da impossibilidade do saber de que é testemunha o outro ato que rompe, a saber, o ato analítico. Em poucas palavras: no limite, encontram-se a vivência da impossibilidade do saber e a vivência - que de algum modo precisa deixar de ser tácita — da falha sobrevivente, a experiência do fracasso da dupla negação afirmadora do saber.

\footnotetext{
${ }^{5}$ Assinala-se que, nos termos aqui transcritos, a autora se refere "em especial" ao ato suicida, mas, de um modo geral, à "passagem ao ato" enquanto tal.
} 
Trata-se de considerar, então, como no percurso analítico, que o ato pode falhar de maneira produtiva. Se por um lado, não está em questão aí, em nome de uma suposta cura, a proscrição desses que se caracterizam como dois mecanismos fundamentais de o sujeito lidar com o objeto, a saber, a passagem ao ato e o acting out, por outro, não se pode conceber que eles orientem paradigmaticamente o manejo da clínica. É bem verdade que a concepção do ato analítico em termos de fim de análise, como a transformação do analisando em analista, o distancia da realidade do tratamento que se inicia. Contudo, considerando-o menos como um estado teleologicamente prometido do que como um marco regulador do tratamento, vemos que é para ele que aponta toda passagem que traz a marca da divisão do sujeito como algo que encerra sua verdade.

Se a passagem ao ato carrega essa marca, é porque a guarda na falha que é constitutiva do seu sucesso. Esse sucesso convém registrar, não deve ser entendido como o êxito suicida que "aniquila o discurso; (...) desata o laço social, diz não a todo saber", mas sim como a conquista sobrevivente da oportunidade da falha. Na passagem ao ato que não tem êxito, a falha é a marca da oportunidade de uma experiência "tão próxima" do ato analítico quanto da dimensão da verdade do sujeito.

Vimos que a passagem ao ato expressa no seu movimento um não-querersaber em que o que é recusado é o que chamamos de experiência da impossibilidade do saber, aquela mesma que traduz o ato analítico de transformação do sujeito. Vimos também que a recusa da vivência de uma impossibilidade, como negação dupla do sujeito suposto saber, como um não-querer não querer o saber, é a atitude que com mais força atesta a confiança do sujeito na sua não-verdade. Vimos por fim que essa dupla negação afirmadora do saber é o ato que não tem êxito em toda passagem que, enquanto outra que não o suicídio, é necessariamente passagem ao ato falha. Nossa pergunta então é: o que tem o tratamento psicanalítico a ver com o caráter constitutivamente falho de toda passagem ao ato?

Temos motivos para acreditar na possibilidade de um tratamento que se oriente pela tarefa de fazer emergir para o sujeito o caráter necessariamente falho da sua passagem ao ato. E acreditamos que o caminho desse reconhecimento depende de que se consiga transferir ou abalar a certeza engendrada pelo objeto que impulsiona o ato, para que o ato falhe de maneira produtiva, a saber, trazendo em sua falha a dimensão da verdade. “[...] o saber, em certos pontos que podem certamente ser sempre desconhecidos, faz falha. E são precisamente esses pontos que, para nós, estão em questão, sob o nome da verdade” (LACAN, 1967-68, 29/11/67).

Mas sabemos também que a verdade do sujeito se localiza no que é, para ele, o objeto a. Pode-se presumir, então, que a "passagem ao ato falha" faz com 
que a verdade do objeto a — consistência lógica com a qual o sujeito faz existir o Outro - seja revelada.

O objeto que causa angústia impede que o sujeito se mantenha no circuito do desejo. Quando o objeto se apresenta no circuito e a falta deixa de operar, o sujeito não pode mais traçar seu movimento impulsionado pela causa de desejo. $\mathrm{O}$ acting out e a passagem ao ato nos mostram que o objeto a precisa ser retirado do circuito, e que é depois do ato que a função causa volta para o lugar. Ocorre entretanto que, no tratamento, o analista não pode nem contar com o advento contingente da experiência da falta nem com a simples passagem ao ato como o caminho para essa falta se fazer.

A aposta do analista deve ser num modo de encontro e delimitação do objeto a que se distingue essencialmente daquele modo de encontro que define a emergência traumática e angustiada da passagem ao ato. Sua intervenção pode propiciar que o objeto, esse em torno do qual o sujeito circula, se desenhe na cena da análise (sem ser pelo caminho do acting out). Uma vez que ele é localizado, pode-se inseri-lo numa montagem da qual fazem parte os outros objetos da história do sujeito, de tal forma que, na estabilidade dessa montagem, reconstitua-se o circuito do desejo. Nesse sentido, acreditamos que mais apropriado do que apostar no surgimento da falta é criar as condições para que a revelação do caráter falho de uma passagem ao ato venha a ser experienciada justamente como um encontro “esvaziado" com o objeto a que está aí, em sua presença. Em poucas palavras a revelação da falha da passagem ao ato pode ser o mesmo movimento pelo qual o objeto a, consistência lógica mas também resto presente, é incorporado na história do sujeito precisamente como motor do circuito do seu desejo.

\section{O CONTORNO DO OBJETO ENTRE UM ATO E OUTRO}

Apresentaremos aqui um fragmento de caso com o qual pretendemos trazer alguma confirmação clínica da conexão entre a falha da passagem ao ato e a verdade do sujeito localizada no que é, para ele, o objeto a.

"Na Polícia ou você é herói ou carrasco, e eu virei carrasco de um dia para o outro". Assim é formulado o sofrimento de um policial que procura atendimento por não conseguir "digerir uma injustiça” que afirma ter sofrido em sua trajetória dentro da corporação: acusado de um ato que diz não ter cometido, passou um ano confinado no xadrez de um batalhão PM até ser julgado e absolvido pela Justiça. Ainda que tenha sido absolvido, a marca da acusação não foi apagada.

O fato de ter ficado preso por algo que afirma não ter feito passa a ser um divisor de águas em sua vida. Antes, "era respeitado porque exercia com afinco e determinação" qualquer missão que lhe fosse atribuída. Agora, acha que não 
pode mais trabalhar nas ruas porque perdeu a "fé pública". ${ }^{6}$ Outro motivo que o "impede" de voltar a trabalhar nas ruas é "o estado de raiva incontrolável" que lhe acomete em certas situações. Passou a temer por seus próprios atos, já que em alguns momentos é "tomado por um descontrole" que o faz "perder a cabeça".

Na prisão, colocava-se diante do espelho e conversava com seu "simétrico” — imagem que representava esse lado irascível com o qual ele começava a conviver. Diz que "essa era uma forma de sentir menos a solidão" e de dialogar com algo que passou a "se opor" a si próprio.

Nos atendimentos, falava basicamente dessa experiência "não assimilada" e da mudança radical, ocorrida a partir dela, em seu jeito de ser e de reagir às situações. "Não me sinto mais pertencendo a esse mundo. Não há lugar para mim aqui".

Estava há pouco tempo em tratamento - irregular — quando, certo dia, apresenta-se no batalhão muito exaltado e com a arma na cintura, o que chamou a atenção dos colegas que sabiam que ele não trabalhava armado. Um colega policial o traz para atendimento, depois de ter encontrado com ele uma folha de papel na qual se podia ler uma única frase: "Filha, hoje eu vou morrer". Enquanto era desarmado, dizia: "vou matar eles".

Prestes a realizar uma passagem ao ato na sessão, ele acaba por sinalizar que sua "capacidade de agir" não podia ser colocada em questão e que o manejo clínico exigia bastante cuidado. Diante da pergunta: "A senhora duvida que eu seja capaz de matar?", impunha-se uma resposta que criasse uma falta entre ele e o Outro. Se de um lado a crença em sua "capacidade de agir" restitui algo de uma dimensão fálica e o extrai do lugar de objeto, de outro, a "capacidade de agir" não recobre tudo sobre ele, havendo algo para além do agir do carrasco que nem ele nem eu sabíamos ainda.

Conta-me, então, que por ocasião de um conflito familiar entre sua filha e sua mulher, a partir do que vinha se sentindo pressionado por ambas, foi tomado por um "acesso de raiva” que o levou a passar ao ato. Após haver deixado claro que estava disposto a acabar com tudo (com a vida delas e com a própria), perseguiu a mulher que, assustada, se refugiara na casa dos pais. Disparou diversas vezes contra o portão da casa. Convencido de que seria preso por esse ato, dirigiu-se ao batalhão "decidido a matar" quem viesse prendê-lo. Chega nesse estado ao atendimento, disposto a "matar e morrer", pois não tem mais nada a perder. Acaba por afirmar que deseja ser "preso justamente", pois só assim poderia digerir a experiência de ter sido acusado por algo que não fez.

\footnotetext{
${ }^{6}$ Expressão corrente no ambiente da Polícia Militar que designa a legitimidade de um ato de autoridade.
} 
O ato cometido no âmbito familiar, que pôs fim ao casamento que ele tanto prezava, aparece em seu discurso não apenas como consequência de uma injustiça sofrida, mas como uma "possibilidade de reparo" dessa injustiça; mas ao preço de sua própria vida. $\mathrm{O}$ ato que o priva da mulher e o deixa, em suas próprias palavras “sem mais nada que prende à vida”, leva a um segundo, que faria jus à marca que o condena: "então, que eu seja preso ou morto por algo que fiz".

Entre um ato e outro, entre uma falha e outra no saber que não dá conta “da injustiça sofrida”, encontra-se o sujeito que persiste - com regularidade e confiança, desde então — na tentativa de localizar possíveis saídas para o que se mostra, a princípio, sem saída. A certeza do "não tenho mais nada a perder", boa tradução, aliás, para a angústia que leva ao ato, não deixa de se apresentar noutros momentos em que há um reencontro com o objeto que causa angústia. É desse objeto mesmo que a análise deve tirar proveito, procurando delineá-lo, estabelecendo seu contorno. Para tal, é preciso produzir um duplo corte: no Outro e no sujeito. No caso apresentado, talvez seja a passagem que vai da marca que o faz estar solapado ao lugar de carrasco à construção de que há algo para além de sua capacidade de agir.

No que diz respeito ao contorno do objeto a, não pode ser desconsiderada a iniciativa desse sujeito de levar uma menina de rua para morar com ele - a menina e seu filho foram acolhidos em sua casa, formando assim sua nova família. O novo compromisso firmado tem todas as características de uma volta a ter algo a perder, condição fundamental para estar outra vez no circuito do desejo.

Recebido em 19/3/2008. Aprovado em 12/6/2008.

\section{REFERÊNCIAS}

ALLOUCH, J. (1997) Marguerite, ou A “Aimée” de Lacan. Rio de Janeiro: Companhia de Freud.

BARROS, L. M. (2005) "Para além dos atos falhos", in BERNARDES, A. C. (Org.). 10 x Freud. Rio de Janeiro: Azougue Editorial.

BRODSKY, G. (2004) Short story: os princípios do ato analítico. Rio de Janeiro: Contra Capa.

LACAN, J. (1953-54/1986). O Seminário livro 1, Os escritos técnicos de Freud. Rio de Janeiro: Jorge Zahar.

(1962-63/2005) O Seminário livro 10, A angústia. Rio de Janeiro: Jorge Zahar.

(1967-68) O Seminário livro 15, O ato psicanalítico. (Mimeo)

(1967-68/2003) "O ato psicanalítico”, in Outros escritos. Rio de

Janeiro: Jorge Zahar. 
(1974/2003). “Televisão”, in Outros escritos. Rio de Janeiro: Jorge Zahar.

MILLER, J.-A. (2005) Introdução à leitura do seminário da Angústia de Jacques Lacan. Opção Lacaniana, n.43, São Paulo, p.7-91.

(2006) Jacques Lacan: remarques sur son concept de passage a l'acte. Mental, n.17, Paris, p.17-28.

SOUZA, N. S. (1991) A propósito do acting-out. Rio de Janeiro. (Mimeo)

. (2005) "A angústia na experiência analítica”, in HANNA, M. S. G. F. e SOUZA, N. S. (Orgs.). O objeto da angústia. Rio de Janeiro: 7 Letras.

VIDAL, E. A. (1993) Passagem ao ato e acting out. Rio de Janeiro: Escola Letra Freudiana, Ano XII, n.1/4, p.211-221.

VIEIRA, M. A. (2005) Objeto e desejo em tempos de superexposição. Ágora - Estudos em teoria psicanalítica v.VIII, n.1, Rio de Janeiro, Contra Capa, janeiro/junho 2005, p.27-40.

Maria Celina Pinheiro Guimarães mcelinapg@superig.com.br 